\title{
Special Investigative Techniques For Human Trafficking Investigation In Ethiopia
}

\author{
Negesse Asnake Ayalew ${ }^{1}$ \\ 1Ethiopian police university college, Ethiopia
}

\begin{abstract}
Keywords: Human

Purpose of the study: The police have the responsibility of balancing the protection of the public from

Trafficking, Surveillances, Undercover Investigation, Intelligence. harm with respecting the human right of the suspect during the prevention and investigation of crimes. However; it is difficult to strike absolute balances since it is determined based on government police is due process or crime control model especially the case of special investigation techniques, which are the covert means of investigation of serious crime and criminals based on the principles of legality, necessity, proportionality, and adequate safeguard. The purpose of this doctrinal article is to evaluate the role of special crime investigation techniques for drug trafficking in Ethiopia.
\end{abstract}

Methodology: Data were collected through document review and interview crime investigators, who were selected purposively since they have a direct relation. This is qualitative research and descriptive design. The collected data were analyzed thematically.

Findings: The findings of this research revealed that there are some provisions of special investigation techniques in FDRE criminal justice policy, anti-human trafficking, and smuggling of migrant proclamation. However, these legal bases are not comprehensive such as the types of special investigation techniques, who conduct it, and how long the requirements to conduct these were not answered.

Application: Therefore, the house of people representative should enact all-inclusive law on special investigation techniques for human trafficking in Ethiopia. The general attorney also should create awareness to the public about it.

Novelty: Human trafficking investigation is challenging ous in Ethiopia, and nobody studied it. Therefore, this study may use as reference material for students'; the government may use it as input for policy and lawmakers.

\section{INTRODUCTION}

The police shall have the objective to maintain and ensure peace and security of the public and the state by respecting and ensuring the observance of the Constitution, the constitutional order and other laws of the country and by preventing and investigating crime through the participation of the public (Mohammed, 2009). The criminal justice system is expected to strike a balance between the protection of the people against criminal harm with suspects or accused against unfair treatment along the process. However, it is unthinkable to achieve absolute balance, which is depending upon the approach of the state towards the due process model or crime control model or a mixed model. The due process model is the emphasis on the avoidance of convicting innocent and tolerates the escape of criminals for the sake of not harming innocents. It is the means justified the end, and the fruit of poisons tree is poisoned, so exclude it.

On the contrary, the policy of the crime control model is the ends justified the end or at any cost of human rights protect e the public. It gives lesser emphasis to the protection of the rights of a suspect or accused, and there is a possibility to convict innocent persons since the significant target is repressing crime. That is why most states adopted the mixed approach based on the nature of the crime and criminal (Mohammed, 2009).

Generally, if the police acquired information through accusation, compliant and personal perception about the commission of the crime, it shall start investigations to identify the truth includes summon and interview witnesses, summon or arrest suspect for interrogation, the search of person and premises and also conduct crime scene investigation send it to forensic science. The criminal investigation is the process of litigation between unequal parties, which is poor, and layman suspects with reach and professional law enforcers. That is why the Federal Democratic Republic of Ethiopia (FDRE) constitution and criminal procedure laws have imposed a duty on the investigator and right for the suspect for fairness, which is an effort to reduce this unbridgeable gap of power and resources between the two parties and in some way leveling the ground. For instances; it set the

\footnotetext{
${ }^{1}$ Corresponding Author: 'bichenalaw@gmail.com
} 
standard for summon, the arrest of the suspect, duty to inform the right to remain silent, brought before a court within 48 hours, due process of law the right to pre-trial access to evidence, open court trial and presumption of innocence and by imposing certain burdens and obligations on the public prosecutor, such as the constitutional obligation to respect and have respected the rights and privileges of the accused, the requirement to prove the charge and to prove it beyond reasonable doubt degree, using third-degree methods are prohibited (Assefa, 2012).

However, for organized crime, unlike an ordinary criminal, have more complex organization structure, transnational modes Operandi, committed by rich and professional persons, and their impact is also more destructive. No universal definition of the phrase "organized crime" due to disagreement on the word "organized" indicates the offenders or the crime. The organized criminal group refers to a structured group of three or more persons, existing for a while and acting in concert to commit one or more serious crimes or offenses in order to obtain, directly or indirectly, a financial or other material benefits such as Italian Mafia, the Chinese Triads, the Colombian drug cartels, the Japan Yakuza and the Nigerian Criminal Groups (Selam, 2019).

Most countries laws allow the use of special investigation and prosecution techniques, which may violate the right to privacy, the rights of suspects will be violated not as an exception instead in most occasions (Selam, 2019). Therefore, organized criminals may have equal barging power with law enforcement, which is the reason for the police are authorized to use special investigation techniques. Ethiopia also has not a compressive law of organized crime. Still, different proclamations defined it as a structured group of two or more persons, existing for a period of time and acting in a concert to commit one or more serious offenses, to obtain directly or indirectly a financial or other material benefits pursuant to the prevention and suppression of money laundering and financing of Terrorism proclamation no. 780/2013 art 2(17)and also prevention and suppression of trafficking in persons and smuggling of migrants proclamation no. 909/2015, article 2. It is ground of penalty aggravation and the FDRE criminal code articles 32-40, which deals degree of participation in the commission of the crime as principal and secondary (Assefa, 2012).

The police may use ordinary and extraordinary investigations techniques based on the nature of the crime and criminal. There is no single universal definition and types of special investigation. The Council of Europe Recommendation (2005) 10 chapter I state that special investigative techniques applied in the study of severe crimes including finical and cybercrime and suspects designed to collect intelligence so as not to alarm the persons concerned (Council of Europe,2005). It means that it applies only to serious crimes and suspects. What is a severe crime? Who is a serious suspect?

\section{METHODOLOGY}

This study is employed as a desktop research approach and a descriptive research design. In exploring and describing laws, institutional frameworks, and practices in Ethiopia, this study follows the qualitative phenomenological approach. This research approach helps to discover and define the lived experiences of human beings within a particular context and a specific time (Creswell, Hanson, Clark Plano, \& Morales, 2007). As far as the writes knowledge nobody conducted a study regarding special investigation techniques for human trafficking investigation Ethiopia. The target populations are police, victim, and human trafficker in Ethiopia.

Tools of data collection were document review and key informants' interviews. Sources of data are primary \& secondary sources. The scope of this study is the practice of human trafficking investigation in Ethiopian. The collected data were analyzed thematically. There is a proper citation, respect consent, and identity of informants for ethical consideration.

Based on the author's observation, some elements of special investigation techniques are found in the FDRE criminal justice system and anti-human trafficking proclamations. Still, there is no certainty on what are the types of special investigative techniques? What are its limitations? What are the principles and procedures to conduct it? The issues of admissibility of intelligence report? Therefore, this uncertainty is motivated by the writer. It is organized into three parts. The first part deals with Human trafficking Investigation. The second part deals with the types of special investigation techniques. The third part deals with the principles of special investigation techniques' in Ethiopia. Finally, the conclusion and suggestions for the concerned body to fill the gaps.

\section{THE CONCEPT OF HUMAN TRAFFICKING}

Irregular migration is a movement of people from one country to the other place within the country or from country to country for various reasons might be or not following or respecting the immigration laws and fulfilling the requirements of the transit and destination countries (Ekmekci, 2017). Therefore, it is a crime committed by the migrant against the law of the transit and destination countries.

Human trafficking is defined in international law in the United Nations Protocol to Prevent, Suppress, and 
Punish Trafficking in Persons, especially Women and Children (the Trafficking Protocol). Ethiopia acceded to the Protocol in 2012. This Protocol supplements the United Nations Convention against Transnational Organized Crime (TOC) 2000. Article 3 of the Protocol defines trafficking as:

Trafficking in persons shall mean recruitment, transportation, transfer, harboring or receipt of persons, by means of threat or use of force or other forms of coercion, of abduction, of fraud, of deception, of abuse of power or a position of vulnerability or the giving or receiving of payments or benefits to achieve the consent of a person having control over another person, for the purpose of exploitation. Exploitation shall include, at a minimum, the exploitation of the prostitution of others or other forms of sexual exploitation, forced labor or services, slavery or practices similar to slavery, servitude or the removal of organs.

However, trafficking in persons is an organized action of recruiting, harboring, and transporting trafficking persons for exploitative purposes. Here there are persons or groups involved in organizing and facilitating the process, called brokers or traffickers, that forced, abused or deceived the trafficking persons into joining the process. Here, the migrants themselves are criminals, and they are not treated as victims, but the trafficking persons are not criminals, rather victims of the brokers' tricks. Smuggling the procurement, to obtain, directly or indirectly, a financial or other material benefits, of the illegal entry of a person into a state party of which the person is not a national or a permanent resident (Ekmekci, 2017).

Human trafficking has three stages (elements) (Mazur \& Lulic, 2007). The first element is the act of trafficking a person refers to the measures employed by traffickers to introduce a victim in the trafficking scenario. These acts become illegal when coupled with the indication that the act was committed without the consent or through the vitiated permission of the victim and evidence that the intent of the conduct was exploitation. The second element is the means (i.e., how) used to traffic a person refers to how a trafficker introduces or maintains an individual in the trafficking scenario. Means employed by traffickers can include fraud, deception, and the abuse of power or a position of vulnerability. They can occur with or without the use of any overt (physical) force. The "use of power or a position of vulnerability" contained in Article 3 of the Protocol "is understood to refer to any situation in which the person involved has no real and acceptable alternative but to submit to the exploitation involved." This is to acknowledge that many trafficked persons are under the influence of someone to whom they are vulnerable, for example, a person holding a position of official authority or a parent or spouse. The lase element is the exploitation of a victim. The common forms of exploitation are a prostitution of others, sexual exploitation, forced labor, slavery or similar practices, servitude and removal of organs.

Moreover, the presence of the consent of the victim at one stage of the process cannot be taken as consent at all stages of the process. If there has not been consent at every step of the process, it means that the case is one of trafficking. This indicates that if a person consented to work abroad or to enter a country illegally, but did not consent to exploitation, an offense has been committed. In the case of children, consent is irrelevant because a child cannot voluntarily or willingly enter into an arrangement that resulted in trafficking, even if the child's parents were to give their consent (Mazur \& Lulic, 2007).

Ethiopia is a source, transit, and to a lesser extent, destination country for irregular migration and migrant smuggling within Africa, as well as to the Middle East and Europe (Regional Mixed Migration Secretariat,2017). In transit, migrants find themselves vulnerable to being kidnapped for ransom, extortion, debt bondage, sex trafficking, and forced labor. Ethiopian girls are exploited in domestic servitude and, to some extent, commercial sex in neighboring African countries, particularly Djibouti and Sudan. Ethiopian boys are subjected to forced labor in Djibouti as shop assistants, domestic workers, and street beggars, in addition to forced criminality. Further, Ethiopian migrants, who have sought the services of recruitment agencies for labor migration to the Middle East, have also become victims of human trafficking at their destination. Ethiopian men and boys also migrate to other African nations, where some are subjected to forced labor Regional (Mixed Migration Secretariat,2017).

The international community has been working on human trafficking control dates back since the parties' conference of 1895 and the adoption of an international agreement for suppression of the white slave trade in 1904. The United Nations also approval a convention in 1949 for the suppression of the traffic in persons and the exploitation of the prostitution of others, the UN protocol to prevent, suppress and punish trafficking in persons, especially of women and children, which is otherwise known as the Palermo protocol in 2000, the convention against transnational organized crime. Ethiopia has ratified most of the general UN conventions as well as several ILO conventions dealing with employment and labor issues such as ILO, the private employment agencies convention (No. 181, 1997); ILO, The discrimination (employment and occupation )convention (No.111,1958); ILO Convention No. 182 on the worst forms of child labor (Kassahun, 2015).

The Federal Democratic Republic of Ethiopia constitution articles 18, (235 and 36, which is the fundamental law of the country, has incorporated pertinent provisions on trafficking. Moreover, proclamation number 104/1989 dealing with the establishment and operation of private employment agencies also contains provisions of a criminal nature reverent to the issue of smuggling of moment children. The anti-human trafficking proclamation also stated that trafficking in persons refers to any person for the purpose of exploitation, at the pretext of domestic or overseas employment or sending to abroad for work or apprenticeship, by 
concluding adoption agreement or at the pretext of adoption or for any other purpose; using threat or force or other means of coercion, abduction, fraud, deception, promise, abuse of power or by using the vulnerability of a person or recruits, transports, transfers, harbors or receives any person by giving or receiving of payments or benefits to achieve the consent of a person having control over another person is punishable with imprisonment 15-25 years and 150000-300000 birr fine. Moreover, accomplice, failure to report it, and accessory after the fact are punishable (Kassahun, 2015).

In August 2015, Ethiopia promulgated Proclamation No. 909/2015 to "Provide for the Prevention and Suppression of Trafficking in Persons and Smuggling of Migrants," which grants victims of trafficking and returnees protection schemes and exclusive rights a rights-based response means victims and others are much more likely to come forward to report traffickers, provide valuable information on the traffickers and act as effective witnesses. Trafficking victims are often forced to commit crimes, such as being forced into prostitution or petty theft. The non-punishment principles stated that trafficked persons should not be detained charged or prosecuted for the illegality of their entry into or residence in countries of transit and destination, or for their involvement in unlawful activities to the extent that such involvement is a direct consequence of their situation as trafficked persons. Such unlawful activities may include petty theft or drug dealing, as well as in jurisdictions where these are criminalized, prostitution, or begging. It grants victims of trafficking immunity from prosecution in relation to illegal acts committed as a consequence of being a victim of human trafficking. Ethiopia has established a specialized investigation and prosecution unit for trafficking in persons and human smuggling at the Federal Police Commission and general attorney.

\section{THE CONCEPT OF SPECIAL INVESTIGATIVE TECHNIQUES}

Every natural person has a human right by nature. So, the government has the duty to protect, respect, and fulfill human rights, such as the right to privacy. One feature of human rights is not absolute, which means due to the right of others, it may be limited by specific laws and derogated in case of the state of emergency (Bantekas \& Oette, 2013). International covenant on civil and political rights (hereinafter refers to ICCPR) Article 17 and

Federal democratic republic of Ethiopia constitution (hereinafter refers to FDRE) Article 26 entitled "Right to Privacy" also stats as:

Everyone has the right to privacy include the right not to be subjected to searches of his home, person or property, or the seizure of any property under his personal possession, the inviolability of his notes and correspondence including postal letters, and communications made by means of telephone, telecommunications, and electronic devices and also government shall respect and protect these rights. No restrictions may be placed on the enjoyment of such rights except in compelling circumstances and in accordance with specific laws whose purposes shall be the safeguarding of national security or public peace, the prevention of crimes or the protection of health, public morality, or the rights and freedoms of others (Bantekas \& Oette, 2013).

This provision states that the right to privacy can be limited if the cumulative requirements of legality, necessity, and proportionality are met. Therefore, special investigation techniques must balance the competing interest of ensuring public safety with the right to privacy, which is the base of the right to freedom of expression and association.

\subsection{Principles of special investigation techniques}

The principles SIT discussed as follows: -

\subsubsection{Principle of Legality}

For effective implementation of these investigations, states have to the comprehensive legal framework and institutional structures with effective control mechanisms such as circumstances and the time in which they can be used, their action limits, and authorization (Bruce \& Schleifer, 2008). ICCPR Article 17 states that a person is protected from unlawful interference into his/her privacy, which means that there is a possibility that one's privacy can be limited when the parliament enacted specific laws to enforce the convent. Therefore; special investigation must be consistent with international human rights obligations and must be conducted on the basis of a legal framework, which must be publicly accessible, clear, precise, comprehensive and nondiscriminatory and that any interference with the right to privacy must not be arbitrary or unlawful, bearing in mind what is reasonable to the pursuance of legitimate aims.

This law must be enacted by parliament and published to be accessible to everyone, which implies a piece of legislation that is published and written in precise manner detail the precise circumstances in which any such interference may be permitted, the procedures for authorizing, the categories of persons who may be placed under surveillance, the limits on the duration of surveillance, and procedures for the use, storage of the data collected and procedural safeguards against undue interference into one's privacy(Human Rights Committee,2015). 


\subsubsection{The principles of Necessity}

The state must demonstrate in specific and individualized fashion the precise nature of the threat that it seeks to address and a direct and immediate connection between the expression and the threat and proportionate to the interest to be protected(John, 2016). If there is an immediate and serious threat to national security like the terrorist act, the law enforcement organ may conduct surveillances. However, In any case, the continuous, realtime interception and collection of suspects' communications and activities for almost five months by police is neither necessary nor proportionate.

\subsubsection{The principles of Proportionality}

Surveillance for national security is often viewed as a legitimate reason but also should be proportional. Proportionality of limitation means there must be a legitimate aim to be pursued by limiting the right, a rational connection between the measure limiting the right and the aim, there must be minimal impairment of the right to privacy, and that a fair balance must be struck between the aim and the right and states are required under international law to provide evidence to justify the interference to the right to privacy (Special Rapporteur, 2014). Therefore, there must be a rational connection between the means employed, and the aim sought to be achieved and should be the last resort and also should, therefore, be judged on the particular circumstances of the individual case.

\subsubsection{The Principle of Adequate Safeguards}

Limitation of the right to privacy is conducted based on a specific law, for a legitimate purpose, and it is proportionate requires some kind of procedural safeguard such as the need for court authorization in order to avoid arbitrariness, executive, and government oversight. Effective measures have to be taken by States to ensure that information concerning a person's private life does not reach the hands of persons who are not authorized by law to receive process and use it, and is never used for purposes incompatible with the right to privacy (Weissbrodt, 1987).

\subsubsection{The Principle of Access to Remedy}

If there is a violation of the right to privacy of a person by law enforcement, there must be a remedy for it, and also, these remedies must be known and accessible to anyone with an arguable claim that their rights have been violated. Moreover, it will involve prompt, thorough, and impartial investigation of alleged violations by those who have the authority to end ongoing violations. Finally, where the target human rights violations rise to the level of gross violations by a law enforcer, there is the civil, criminal, and administrative liability of the right violator and also the exclusion of illegally acquired evidence (Fengler, Eberwein, Mazzoleni, Porlezza, \& Russ Mohl, 2014).

\subsection{Forms of Special Investigation Techniques'}

Special investigation techniques are numerous, varied and constantly evolving and that their common characteristics are their covert nature such as delivery control, surveillance, undercover investigations and intelligence, witness protection and the fact that their application could interfere with fundamental rights and freedoms except for peremptory norms of international law and international humanitarian law(Philip and others,2010). These are the means of information collection, which is yesterday's Information becomes today's Intelligence, which becomes tomorrow's Evidence to prove the fact in issue.

\subsubsection{Control Delivery}

It is the technique of allowing illicit or suspect consignments of narcotic drugs, psychotropic substances, or substances substituted for them, to pass out of, through or into the territory of one or more countries, with the knowledge and under the supervision of their competent authorities to uncover drug trafficking across the network, from the grower, manufacturer and distributor to buyers and consumers pursuant to Convention on Illicit Traffic in Narcotic Drugs and Psychotropic Substances, signed at Vienna on 20 December 1988 article 1. This technique is used to trace the flow of illicit goods such as drugs, wildlife specimen, counterfeit products or falsified medical products to determine their true sources, transit routes, and destination and also it enables the mapping of complete criminal schemes and structures of organized criminal groups for the purpose of investigation and prosecution. Therefore, for illicit products, trafficking is identified or intercepted in the source, or transit then delivered under surveillance to identify the intended recipients and subsequent distribution within an organized criminal group or in the illegal supply chain. However, these aren't advisable for trafficking in person because the police give priority for the protection of the victim than surveillances of the suspect (Castellanos-Gomez et al., 2013). 


\subsubsection{Surveillances}

The word surveillance is derived from the French word "surveilled," which means to systematic, discreet watch over to develop information regarding a suspicious person's activities. Surveillance or spy is a criminal act for the private person. Still, for the government it is the lawful act to obtain information for a search warrant, locate a subject, contraband, or the site of illegal activities, to obtain intelligence about a subject, criminal group or location, prevent a crime from occurring through covert or overt surveillance, to gather intelligence for a raid, provide protection for informants, undercover individuals or others (Tam et al., 2005). For instance, in Ethiopia, the national security and intelligence services, the federal police, the nine regional police, and two city administration commissions, custom and revenue authority, minister of defenses, etc. have their intelligence and surveillance department.

There are two forms of surveillance, such as physical or electronic surveillances, based on tools of surveillance (Tam et al., 2005). Physical surveillance refers to the human act of secretly and continuously or periodically watching and recording (photo, video, sketch, and note-taking) of suspected persons, vehicles, places, and objects to obtain information concerning the identities and activities of individuals, which must go undetected by the target, usually abandoned or change another surveillance if the target detects it and it must blend in with the environment. ${ }^{1}$ If the target uses foot, the inspection also conducts on foot; if the goal uses any means of transport (vehicle, airplane, helicopter, etc.), the surveillance person also uses the same means of transportation. Moreover, if the target has a fixed workplace like an office or shop, the surveillance person also should have a similar workplace.

Electronic surveillances, which refer to real-time surveillance, recording, listening, and acquisition, viewing, controlling, or any other similar act of data processing service or computer data by using the computer (Coates et al., 2015). All phone calls and broadband Internet traffic such as emails, web traffic, instant messaging, social network site such as Facebook, telegram, twitter is under the support and control of law enforcement. They run a pinwale database to stores and index large numbers of emails of everybody and also possess Stingrays tracker technology to activate the microphones in cell phones remotely by accessing phone diagnostic or maintenance features to listen to conversations that take place near the person who holds the phone. All countries did not allow electronic surveillance due to disagreement on where it is permitted, for which crime and its requirements, and the intrusive nature of electronic spying. It needs strict judicial control, legal safeguards, and a severe only crime. It performs a similar function to undercover operations but allows for the collection of a broader range of evidence, and physical infiltration or surveillance would represent an unacceptable risk to the investigation. ${ }^{2}$ It includes interception of phone communication, recovery of incoming and outgoing calls, and position location.

It has the following four forms of surveillance based on their technology. Firstly, audio surveillance used to gather intercepted and recorded videos using phone tapping, voice over Internet protocol, listing devices, and listening devices. Secondly, visual surveillances are hidden video devices, in-car video systems, body warm video devices, thermal images, and CCTV. Thirdly tracking surveillances use to identify the location of the target through global positing system transponders, mobile phones, radio identification devices, and biometrics info technology. Data surveillances are the gathering of data from the computer through a computer, mobile phone, and keystrokes monitoring (Mazur \& Lulic, 2007).

To use both physical and electronic surveillance forms, the state shall have a law, which gives the answer to the questions (Coates et al., 2015); who authorized for surveillance operations? What are the preconditions for conducting surveillance operations? Is authorization from a judicial or other independent source required? What are the limits and conditions for surveillance orders and standard operating procedures? However; the broad surveillance powers of law enforcement articulated in different country laws are lack of legal safeguards that limit the nature, scope, and duration of surveillance measures, and grounds for judicial approval, raises concerns that these powers are not adequately regulated to prevent arbitrary, unlawful or disproportionate interference with the right to privacy. For instance, a court warrant is required to conduct surveillance on targets, but there is no opportunity to challenge the admissible of surveillance since disclosing the means and source of it is not disclosed.

\section{$\overline{\text { 4.2.3. } \quad \text { Undercover investigation }}$}

It is the third means of special investigation technique in which the agent is acting under a different identity than the real one, who constructs a scenario in order to gain the trust of a person in order to establish an offense or gathering information related to crime and interaction to discover evidence leading to involvement in establishing the facts investigated. It is three forms are the first infiltration of specially authorized law enforcement officials undercover identity such as he/she may be appointed as

\footnotetext{
${ }^{1} \mathrm{lbid}$

${ }^{2}$ Brian D. Baker and Whitney, supra note 15
} 
secretariat or driver or record officer within an organization, then record each activity of the target and report to the authorized person. Secondly, pseudo or test purchases or services of illegal goods like the police may act as drug and firearms buyers. Thirdly befriend approach a specific suspect or participating in control deliver (Kruisbergen, de Jong, \& Kleemans, 2011). It occurs where investigators in different identity infiltrate criminal networks or pose as offenders to uncover organized crime activity. The law of the country shall answer the following questions in what kinds of cases and in which format are these allowed, are there limits on its type, what are the preconditions for conducting is an authorization from a judicial or other independent source required, are there guidelines for the appropriate use of undercover officers?

The first organized informal undercover program called Security Brigade was first employed in France in 1811, which was later converted to a security police unit under the Prefecture of Police. In 1829 by Sir Robert peel established the modern police of England, including plainclothes undercover detectives. Its role was counterterrorism, combating foreign subversion, and infiltrating organized crime. The United States of America also was established by the Federal Bureau of investigation, including undercover investigators in 1908. Their role is to be part of an existing criminal enterprise, but most countries prohibiting undercover agents from providing opportunities to commit a crime, instigating, and committing crimes themselves. The US regulates it through case laws; it applies to any crime, and the agent allowed instigating. Whereas Netherlands, Belgium, Germany, and England have form act, apply only for serious misconduct and criminal only if there is absolute seriousness (proportionality) and last resort (Davis \& Bennett, 1984).

\subsubsection{Criminal Intelligence}

Intelligence is a systematic approach for converting information into intelligence and making that intelligence available to decision-makers. Intelligence is only now starting to develop holistic assessments of law enforcement's strategic operating environment that, in turn, can be used to support executive strategic decision-making (IACP,2002). Criminal intelligence, depending on circumstances it may well are housed in information, either in police units, customs, and prisons or even in military organizations. Given the trans nationalization of organized crime, internal security has traditionally gone to the Police Forces, and the Armed Forces have been responsible for external security became merged then the holistic nature of criminal intelligence, characterized by approaching the analysis and interpretation of an issue or a situation from a multidisciplinary perspective and integrating information from all types of sources. It has the analysis and interpretation of an issue or a situation from a multidisciplinary approach, the integration of data from all sources, and its processing by a team (Daniel,2015). It is a purpose to collect, analyze, and disseminate information that assists policymakers, law enforcement, and other public entities in taking measures to protect national security and human rights (Davis \& Bennett, 1984).

\subsubsection{Witness Protection and Immunity}

FDRE the Protection of Witnesses and Whistleblowers of Criminal Offences, Proclamation No. 699/2010 states that whistleblower or witness means a person who has given or agrees to give information or has acted or agrees to act as a witness in the investigation or trial of an offense. These people need different protection through whistleblower protection laws against retaliatory from organized criminals, immunity from criminal depend on the value of the suspect's evidence provided, and its actual impact, law enforcement organ has a duty to the confidentiality of the identity of whistleblower and witness and also if the boss retaliates the whistleblower, the duty of burden is on the accused boss. It shall be applicable with respect to testimony or information is given, or investigation was undertaken on a suspect punishable with rigorous imprisonment for ten or more years or with death without having regard to the minimum period of rigorous imprisonment. Where the offense may not be revealed or established by another means otherwise than by the testimony of the witness or the information of the whistleblower and where it is believed that a threat of serious danger exists to the life, physical security, freedom or property of the witness, the whistleblower or a family member of the witness or the whistleblower. Similarly, Ethiopian draft criminal procedure code article 139 also states that when the undercover investigator has committed the crime in the conditions of last resort, necessary, and proportionality, he/she is immune from prosecution.

\section{Special Investigation Techniques for Human Trafficker in Ethiopia}

Investigation techniques are varying on whether a particular jurisdiction happens to be a place or country of origin, transit, or destination (Mazur \& Lulic, 2007). In countries of origin, the investigation is likely to focus on the recruitment aspect of the crime, such as methods of coercive or deceptive. Whereas places of transit are in a more suitable position to gather intelligence on modes of transport, routes used by traffickers, safe house en route to the destination, and crimes related to the use of travel documentation. Places of destination focus on the exploitation aspect of the crime. Ethiopia has established a specialized investigation, prosecution, and trial unit for trafficking in persons and human smuggling at the Federal Police Commission.

The FDRE Criminal Justice Policy enacted by the council of the minister in 2011 under section 3.17 states that special investigative techniques are necessary to prevent and investigate organized crime, complex economic, and corruption crimes. 
According to this policy the common forms of special investigative techniques are electronic and physical surveillance, Infiltration to organized crime and creation of a simulated legal relationship, and also the standard to conduct these are the existence of "reasonable suspension" for the commission of a serious and medium crime with a court warrant. However; if there is "sufficient suspension" for the commission of an imminent, serious crime and unable to find evidence through convectional investigation tactics, the police may conduct an interception of communication of the suspect without a court warrant, but it needs federal high court president approval as soon as possible.

\subsection{Surveillance and Undercover Investigation}

The police should collect information through surveillance and undercover officers then change this information into intelligence and evidence. For instance, undercover officers through test purchases best gather information. It is the deployment of one or more officers to purchase the services of trafficked persons (Radulescu and Holmes, 2003). Normally, currency notes whose numbers are carefully registered beforehand will be used for payment and will later be used as evidence. The infiltrator can enter the premises where exploitation is taking place and secretly recorded then report the number of victims, the layout of the premises, exit and entry points, hidden compartments, and busiest hours of business. The police changed this information into intelligence than conduct raid operations to arrest traffickers.

The FDRE Criminal Justice Policy is a government direction, which is enforced by specific laws such as prevention and suppression of trafficking in persons and smuggling of migrants Proclamation No 909/2015 Article 3, 18(2), 19, 26-30 provide that where there are reasonable suspensions to believe that human trafficking and smuggling of migrants has been, is being or is likely to be committed the police with court warrant;

- May conduct undercover investigation such as infiltrate the suspected criminal groups and create a simulated legal relationship like a marriage or business relationship. Moreover, the undercover investigator is immune from prosecution even if he/she committed a crime during its operation unless he/she causes death on the victim or commits rap; the suspect who gives substantial evidence to an investigator is immune from prosecution.

- Conduct physical surveillance such as fixed or moveable against suspects and also may conduct an electronic inspection, including private intercept communication of the suspects to like know call history, location indication to collect evidence to prove the crime. However, the police may conduct intercepting communication of the suspects for urgency by order of general attorney only, which needs the approval of federal high court president within 72 hours.

- The use of exclusive privileges and the period of limitation is also prohibited.

From these articles, we can understand that unlike ordinary crime investigation based on the criminal procedure code of Ethiopia, this proclamation authorized police to use special investigation techniques. However, the use of undercover investigation such as infiltration into human traffickers up to creating the legal relationship and commit crime except for homicide and rape. However, what about the infiltrator initiate a trafficker to commit it and committed torture? But there is no certainty on what the types of special investigative techniques are. What are its limitations? What are the principles and procedures to conduct it? The issues of admissibility of intelligence report?

\subsection{Immunity of Witness and Victim}

This means victims and others are much more likely to come forward to report traffickers (provide valuable information on the traffickers and act as effective witnesses. Police training should acknowledge the practical value of providing incentives for trafficked persons and others to come forward to report traffickers (Guideline 5.2).

Many victims of trafficking do not cooperate with police due to low awareness, suffering retaliation for exposing their trafficker, fear of prosecution for entering the country illegally, working illegally or engaging in activities which are criminalized in the country, such as prostitution, soliciting or begging. Moreover, the lack of basic need provision during the prosecution period, which may take years. Ethiopia, in cooperation with the International Organization for Migration, has established Migrant Response Centers at three high volume transit areas located on the Northern, Eastern, and Southern migration routes. These are at Metema (via Sudan and Libya to Europe), Afar (via Galafi and Djibouti to Yemen), Somali (via Togo-wuchale, Somaliland, Bosasso and Yemen to Saudi Arabia) and Moyale (via Kenya to South Africa) areas, respectively (IOM,2019). These centers register all received persons and provide them with immediate assistance such as water, food, medical treatment, temporary shelter, service referrals, and protection under guarded premises, as well as longer-term support rehabilitation services, such as trauma counseling. This includes screening to determine whether the individual is a victim of trafficking or migrant abuse and a needs assessment to determine the specific assistance and protection required by the individual. The investigator also has the duty to identify the victim then provided legal, health, social like shelter outside the police station and psychological service and also immune from prosecution even if they are committed other related crimes like smuggling and use of the illegal documents. 
Moreover, victims and witnesses are entitled to the protections stipulated under Witness and Whistleblowers Protection Proclamation no. 699/2010, which includes the investigator's duty to conduct a risk assessment with the safety of victims and their families before, during, and after the criminal justice system and provide protection for them. Family and community members of human trafficking victims are relevant evidence to prove the case. Therefore, Police must provide effective protection for witnesses from potential retaliation or intimidation in criminal investigations. Moreover, it needs to assess the needs of witnesses and inform them as they are not liable for other crimes committed by them. Practically, the federal police commission pays a daily allowance for the victim, conduct real-time despatcher (RTD), and preliminary inquiry to register evidence. Moreover, community policing officers create awareness to the public about the impact of human trafficking and participate in the integration of victims with the community.

\title{
5.3. Parallel Money Launder Investigations
}

Human trafficking is a predicate offense to generate profit, and also, the trafficker launders this profit, which is the principle of following the money, and you will find the trafficker. The purpose of the trafficker is money generation then conducts money laundry (Mazur \& Lulic, 2007).

The Ethiopian Criminal Code Art 684 and Anti-Money Laundering Proclamation No. 657/2009 new replied by Proclamation No. 780/2013 criminalized money laundry and established a Financial Intelligence Centre (FIC). This proclamation does not define money laundering but explains the requirements for an offense to be a money laundering offense. Art 29 of this proclamation defined as:

\begin{abstract}
Any person who knows or should have known that a property is the proceeds of a crime and who converts and transfers the property for the purpose of concealing or disguising the illicit origin of the property or of assisting any person who involved in the commission of a predicated offense to evade the legal consequences of his actions; conceals or disguise the true nature, source, location, disposition, movement or ownership of or rights with respect to the property; acquires, possesses or uses the property, or participates in the commission, conspires to commit, attempts to commit or aids, abets, facilitates or counsels the commission of any of the elements of the offenses mentioned in the paragraph ' $a$ ' to 'c' of this article.
\end{abstract}

This means that the process of placement, layering, and integration of illegtiment wealth with a legitimate one. It also states that all cash deposits and withdrawals exceeding 200,000 birrs in local currency and 10,000 dollars or equivalent in other currencies are required to be reported to the Financial Intelligence Centre (FIC). This proclamation Article 25-26 allowed the use of special investigation techniques such as surveillance, undercover investigation, and control delivery.

\section{CONCUSSION}

Crime investigation is the process collection of evidence to prove the fact in issue based on the law of the country. Usually, these laws recognized some rights to the suspect and imposed a duty to respect human rights on the investigator to level the playing field. However, for serious crime and criminals, the police authorized to use specialized special investigation techniques, which is the covert means of a collection of information from the suspect when there are the principles of legality, necessity, proportionality, and adequate safeguard.

There are some provisions of special investigation techniques in FDRE criminal justice police, anti-human trafficking, and smuggling of migrant proclamation. However, this legal basis is not enough, such as the types of special investigation techniques, who conduct it, and how long, for which crime and criminal, the requirements to conduct these were not answered. Therefore, the house of people representative should enact a law on special investigation techniques for drug trafficking in Ethiopia.

\section{REFERENCE}

Assefa, S. K. (2012). The Principle of the Presumption of Innocence and its Challenges in the Ethiopian Criminal Process. Mizan Law Review, 6(2), 273-310.

Baker, B. D., \& Gunter, W. D. (2005). Surveillance: concepts and practices for fraud, security and crime investigation. Int. Found. Prot. Off, 2, 1-17.

Bantekas, I., \& Oette, L. (2013). International human rights law and practice: Cambridge University Press.

Bronitt, S. (1997). Electronic surveillance, human rights and criminal justice. Australian Journal of Human Rights, 3(2), 183207.

Bruce, R. D., \& Schleifer, R. A. (2008). Ethical and human rights imperatives to ensure medication-assisted treatment for opioid dependence in prisons and pre-trial detention. International Journal of Drug Policy, 19(1), 17-23. 
Bruce, R. D., \& Schleifer, R. A. (2008). Ethical and human rights imperatives to ensure medication-assisted treatment for opioid dependence in prisons and pre-trial detention. International Journal of Drug Policy, 19(1), 17-23.

Castellanos-Gomez, A., Roldán, R., Cappelluti, E., Buscema, M., Guinea, F., van der Zant, H. S., \& Steele, G. A. (2013). Local strain engineering in atomically thin MoS2. Nano letters, 13(11), 5361-5366.

Coates, A. S., Winer, E. P., Goldhirsch, A., Gelber, R. D., Gnant, M., Piccart-Gebhart, M., . . . André, F. (2015). Tailoring therapies - improving the management of early breast cancer: St Gallen International Expert Consensus on the Primary Therapy of Early Breast Cancer 2015. Annals of oncology, 26(8), 1533-1546.

COUNCIL, O. E. (2005). Council of Europe Framework Convention on the Value of Cultural Heritage for Society. Rada Europy, Strasbourg.

Creswell, J. W., Hanson, W. E., Clark Plano, V. L., \& Morales, A. (2007). Qualitative research designs: Selection and implementation. The counseling psychologist, 35(2), 236-264.

Davis, J. Q., \& Bennett, V. (1984). Brain ankyrin. A membrane-associated protein with binding sites for spectrin, tubulin, and the cytoplasmic domain of the erythrocyte anion channel. Journal of Biological Chemistry, 259(21), 13550-13559.

Ekmekci, P. E. (2017). Syrian refugees, health and migration legislation in Turkey. Journal of immigrant and minority health, 19(6), 1434-1441.

Fengler, S., Eberwein, T., Mazzoleni, G., Porlezza, C., \& Russ Mohl, S. (2014). Journalists and media accountability: An international study of news people in the digital age (Vol. 12): Peter Lang.

Holmes, P., Radulescu, M., \& Velikonja, M. (2003). Law enforcement manual for fighting against trafficking of human beings.

International Assoc of Chiefs of Police, \& United States of America. (2002). Criminal Intelligence Sharing: A National Plan for Intelligence-Led Policing at the Local, State and Federal Levels.

John Doe (Kidane) v. (2016) The Federal Democratic Republic of Ethiopia, Brief of Amici Curiae, United Nations Human Rights Experts in Support of Plaintiff-Appellant and Reversal, D.C. Ct. App., Case No. 16-7081, pp. 14-15, 17-18.

Kassahun, M. (2015). Secure Routing in Structured P2P Overlay: Simulating Secure Routing on Chord DHT. In.

Kruisbergen, E. W., de Jong, D., \& Kleemans, E. R. (2011). Undercover policing: Assumptions and empirical evidence. The British Journal of Criminology, 51(2), 394-412.

Kruisbergen, E. W., de Jong, D., \& Kleemans, E. R. (2011). Undercover policing: Assumptions and empirical evidence. The British Journal of Criminology, 51(2), 394-412.

Mazur, N., \& Lulic, M. (2007). Trafficking in women for the purpose of sexual exploitation on the territory of the former Yugoslavia. Pravni vjesnik, 23, 155.

Mazur, N., \& Lulic, M. (2007). Trafficking in women for the purpose of sexual exploitation on the territory of the former Yugoslavia. Pravni vjesnik, 23, 155.

Mohammed, K. (2009). Ethiopian Criminal Procedure Teaching Material.

Secretariat, R. M. M. (2017). ethiopia country statement addressing migrant smuggling and human trafficking in east africa, ['RMMS'],pp. 1 .

Selam, H., \& Sibhatu, G. (2019). In vitro antimicrobial activities of crude extracts of Vernonia amygdaline and Croton macrostachyus against some bacteria and fungi test pathogens. Journal of Phytopharmacology, 8(2), 57-62.

Tam, L. S., Li, E. K., Leung, V. Y., Griffith, J. F., Benzie, I. F., Lim, P. L., . . Thomas, G. N. (2005). Effects of vitamins C and $\mathrm{E}$ on oxidative stress markers and endothelial function in patients with systemic lupus erythematosus: a double blind, placebo controlled pilot study. The Journal of Rheumatology, 32(2), 275282.

Weissbrodt, D. (1987). Country-Related and Thematic Developments at the 1988 Session of the UN Commission on Human Rights. Hum. Rts. Q., 10, 544.

Weissbrodt, D. (1987). Country-Related and Thematic Developments at the 1988 Session of the UN Commission on Human Rights. Hum. Rts. Q., 10, 544. 